\title{
Connecting Research, Teaching And The Student Experience In Innovative Ways Through Participation At Major Sports Events

\author{
Veronica Velo, Coventry University, UK
}

Herve Fournier, Institut Hotelier Cesar Ritz, Le Bouveret, Switzerland

\begin{abstract}
This paper showcases on the contribution of Cesar Ritz Colleges (CR) at supporting the organization and running of support services at a major international sports event and the Swiss National Hospitality House in the Athens and Torino Olympics. Through the description of how CR managed to connect the knowledge developed by their students in the classroom with the catering of the House of Switzerland during the Olympic Games in Athens and Torino and then by elaborating on how the experience obtained through this exercise was reincorporated in their teachings. This article draws on the possibilities that academic institutions can optimize their curriculum in order to produce a more complete and comprehensive pedagogical experience, that is significantly in-line with the needs of the industry.
\end{abstract}

Keywords: Olympics, catering, sports events, learning by doing, hospitality houses, international events.

\section{INTRODUCTION}

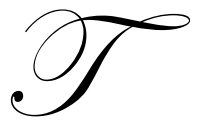

he research methodology to be used in this case is the Case Study analysis. Based on the experience of Cesar Ritz Colleges, a model for active learning methods will be developed. The whole adventure started when Cesar Ritz Colleges were contacted by the Department of Foreign Affairs of the Swiss Government through its agency "Presence Suisse" in their search for bids from several Hotel Management Schools to manage the Official Restaurant of the Swiss official delegation in Athens at the Olympic Games of 2004.

\section{The House Of Switzerland And Presence Suisse}

Presence Suisse, in its role of promoting Switzerland as a tourist destination and to boost the Swiss economy in general overseas, saw an opportunity in the Olympic Games in Athens to enhance the country's image abroad. Previous to the Athens games, the House of Switzerland had been managed by Swiss Olympic. Presence Suisse had already been active at supporting and organizing major international events in the past, such as the World Exposition in Japan and is still very much involved in this type of activity, in particular the forthcoming exposition taking place in Shanghai in 2010. As part of the Ministry of Foreign Affairs, Presence Suisse was in a privileged position in terms of contacts with all Swiss embassies, which would facilitate the task of the bid winners in terms of minimizing legal issues for operating locally, accessing convenient and appropriate rental contracts and assisting in the importation of raw materials necessary for operations.

The House of Switzerland is the official venue where the Swiss delegation, the Swiss media and the Swiss athletes meet outside the Olympic village. Other hospitality houses like the House of Canada, the House of America or the House of Austria cover similar functions, but what is unique about the House of Switzerland compared to other nations is that it is open to the public: Swiss fans, international members of other delegations, fans from other 
nations, and people just wanting to feel like they are in Switzerland during the Olympics were welcome (Mistelbauer, 2006).

In 2003 Cesar Ritz Colleges won the bidding competition which took place among five hospitality schools and one private entrepreneur. The agreement with Presence Suisse stipulated that if the Athens experience was successful, Cesar Ritz Colleges would be in charge of the catering of the House of Switzerland for three consecutive Games. This seemingly straightforward agreement proved to be more challenging than initially expected, as the business environment and conditions were different in each case.

The key success factors that ensured Cesar Ritz Colleges' victory in the bidding competition included: their original suggestion to combine Swiss gastronomy with local cuisine and the fact they were offering to showcase Switzerland with a crew of young motivated students from very different countries including 16 nationalities and 23 spoken languages. Students participating were representative of the main Olympic countries.

This particular choice of showing the very international face of modern Switzerland, including the successful integration of natives from different horizons was perceived by the judges of the selection committee as a strength, though many patrons perceived it as a drawback. Some customers did not appreciate the fact that their typical Swiss dishes were served by students that did not represent a more traditional image of the nation. The management of the balance between showing a modern-intercultural country while celebrating its traditions was one of the challenges to be overcome by the team in terms of brand constitution.

\section{THE PREPARATION AND MANAGEMENT OF THE EVENTS AS A LEARNING PROCESS}

The management of each of the events was integrated as a learning experience both for the selected team traveling to the Olympic destinations and for the other students taking classes on campus.

\section{The Preparations For The Event In Athens}

As soon as the success of the bid was announced, the class taking the Events Management module was allocated the responsibility of organizing a press conference to publicize the good news. Other classes were in charge of preparing three different banquets: the first one to welcome VIPs involved in the Athens Games including the Director of Swiss Olympic, the second one to congratulate the departure of the selected student delegation and a third one to welcome them back.

The constitution of the group of students who would directly participate in the running of the House of Switzerland at the Olympic location took place through a competitive interview process. The selection criteria included aspects such as the origin of the students (as they should be representative of the countries participating to the Games), the outcome of their previous work experience (internship) in Switzerland, as well as their academic and behavioral performance so far in their studies (the minimum requirement was having completed at least one year of studies at Cesar Ritz Colleges).

Once the selection process was finalized, a very comprehensive and intensive series of teambuilding exercises took place in order to prepare the delegation for the upcoming mission. These activities included group sport competitions, objective-driven games, visits to sites, specially organized lectures on group development, and establishing liaisons with providers and stakeholders in the initiative. These activities were voluntarily run by Cesar Ritz Colleges staff members on top of their standard workload and their major aim was to ensure the cohesion of the group prior to traveling.

\section{The Challenging Organization Of The Youth Olympic Festival In Champery}

Following on their success in Athens, Cesar Ritz Colleges were invited to organize and run the catering operations for the European Youth Olympic Festival of Monthey, Switzerland, in 2005. 
The event took place over one week during the school term. In order to fit the activities within the schedule, time-tables were modified to make it possible to have 120 students involved in the activities. 42 European Nations were represented in the Youth Olympic Festival Event, with 800 fourteen to seventeen year old athletes competing in 7 winter sports plus 400 officials and 600 volunteers to be logistically organized and fed.

Within 7 days, 29,000 meals were served by Cesar Ritz Colleges' students in a 1,200 seat venue. Also, 5 VIP Events for 250 to 450 guests from the Olympic Committee took place at the Crochetan theatre in Monthey (Western Switzerland). All these marathon logistics took place during a normal week of classes, so students and staff managed to work up to 19 hours consecutively, some days.

The event resulted in an absolute success in terms of local visibility of the school, and more importantly, as a learning experience for the students and at a managerial level. These favorable outcomes went beyond the mere sustainability of the corporate brand, to positively impact the whole region of Chablais-Portes du Soleil and of the Valais in general. One of the numerous beneficial outcomes resulting from these operations was that it allowed -through appropriate budget management-- the generation of a CHF 150'000 fund that was allocated to the constitution of a local foundation for the promotion of sports for youth.

\section{The Experience In Torino}

Following the successful experience in Athens, the partnership with Presence Suisse was renewed for the Olympic Games in Torino. The complexity of the situation this time was doubled, as on this occasion there were 2 restaurants to be managed and not just one, as the Alpine ski activity (one of the Swiss team's strengths) was to take place in Sestriere (approximately $110 \mathrm{~km}$. away from Torino), so it deserved a particular venue as well. An extra financial threat was added to this very particular challenge because Winter Olympic events are less popular than Summer ones, the search for funds and the establishment of partnerships might have been more difficult.

Fortunately, the specific location of Cesar Ritz Colleges provided a solution to the expected problem. The school is located in the Swiss canton of Valais, the capital of which, Sion, had competed with Torino to host the 2006 Olympic Games. The region has a longstanding tradition of winter sports that attracts many Italian visitors each year. In fact, so important was Northern Italy as a target market for the Valais region that Cesar Ritz Colleges managed to persuade the State Tourism Board of Valais to become the major partner in this initiative in order to increase the visibility of the Swiss slopes within this preferred group of customers.

In the pursuit of such exposure, the State Tourism Board of Valais did not only invest more than $\mathrm{CH} 1$ million in the initiative, they also prompted Swiss Tourism to participate as well. These latter partners had not wanted to contribute to the Athens experience because they did not recognize the importance of Greece as a relevant economic source of tourists.

With both the State Tourism Board of Valais and Swiss Tourism on board as partners, the budget concern was not an issue any more. The two venues (Sestriere and Torino) were a success, in which a particularly important role was played by the Piazza Svizzera. This included a collection of food stands with music that attracted an interesting number of visitors, because they offered the possibility to continue the celebrations in a festive way after the medal award ceremonies every evening.

As well as for the event in Athens, the preparation activities were cleverly and smoothly incorporated in the curriculum. Once again, the Events Management class organized a press conference and other classes put together a few banquet nights. The selected delegation again participated in a series of teambuilding exercises and visited the partner suppliers (cheese producers, wine producers, other sponsors) in order to ensure cohesion and commitment.

In terms of industry partners, Presence Suisse, Swiss Olympic and Cesar Ritz Colleges played a role in establishing a productive and powerful network of collaborative links. 
Presence Suisse established the links with big Swiss multinationals such as Swiss Airlines, Nestle, UBS and others. These companies either brought their own networks to the House of Switzerland, or they organized public relations activities such as a daily raffle. Cesar Ritz ensured and maintained the relationships with the Gastro partners, who would contribute either by offering goods for free or at a reduced price to be showcased in exchange. Loyalty played an important role for Cesar Ritz Colleges at the time of choosing its partners for the Torino experience. They kept the relationships they had initiated with the suppliers that had trusted them during the Athens Games as they were considered part of the team, instead of calling for bids from different producers (which might have resulted in lower input prices).

Swiss TV (SRG -SSR) was also a partner. According to protocol, the House of Switzerland was not just a catering venue. It was also the location where athletes were constrained to appear in order to celebrate medals and diplomas. It was also part of the protocol for winners to attend to the House of Switzerland to meet and publicly shake hands with the President of Swiss Olympic, then be brought on stage in order to answer questions and participate in interviews organized by the press to finally have dinner with their entourage. Protocol also included Champagne opening, and cake cutting. The House of Switzerland functioned therefore as a live feed to interview athletes and where there were always several flat screen televisions showing live what was being broadcast in Switzerland. Wireless internet was available everywhere so that journalists could work productively.

Figure 1 illustrates the different roles of the partners involved in the Torino Event.

Figure 1

Organizational Chart House of Switzerland Torino 2006

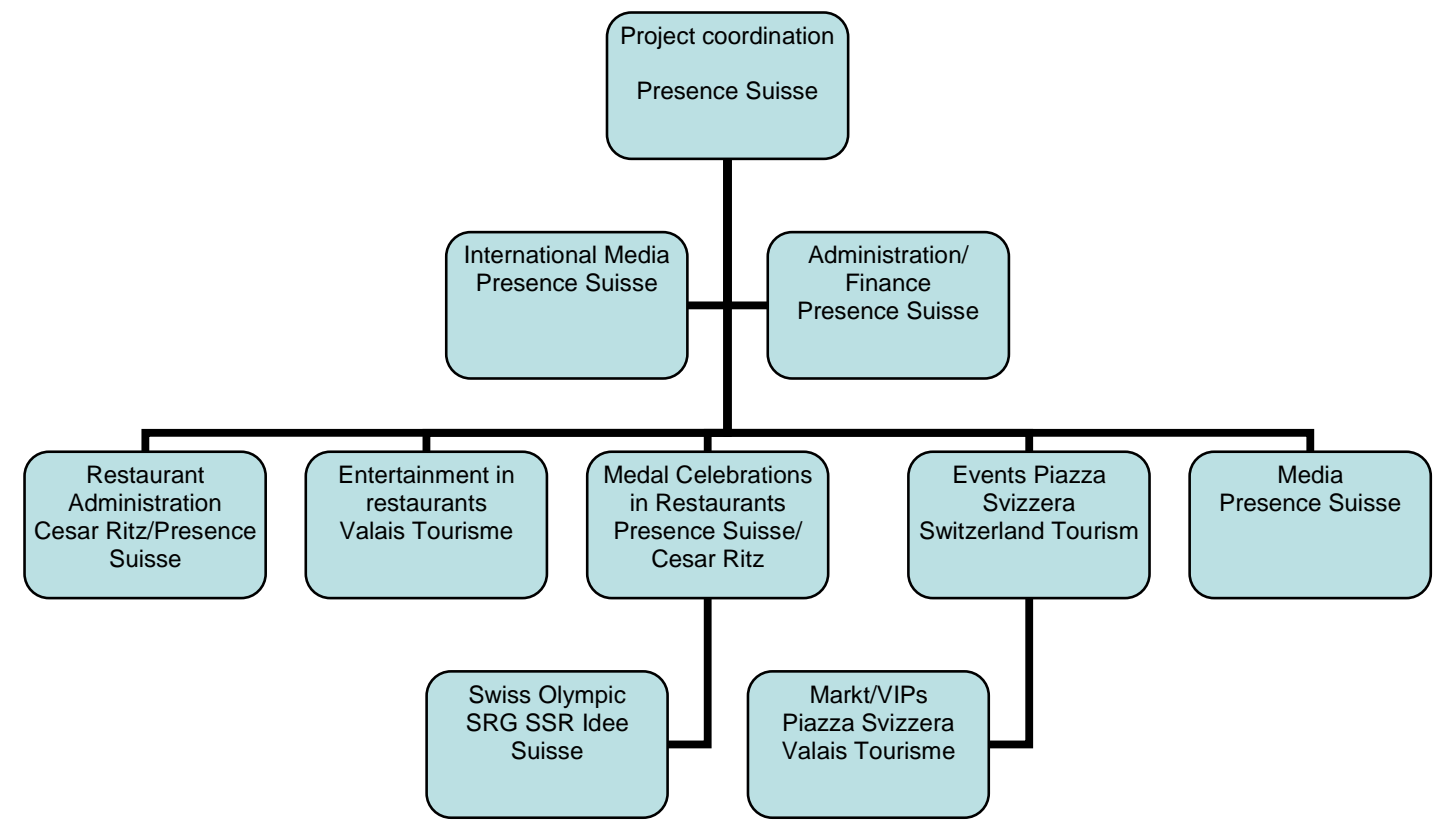

Source: Präsenz Schweiz/ M. Hueter/Mai 2006 


\section{THE STUDENTS VIEW}

\section{The Event From The Student Perspective}

When interviewed on the pedagogic outcomes of the overall experience, students mentioned that the major learning areas had to do with time management and the value of good organizational skills. Participating in such a marathon of time constraint exercises did nothing but vaunt the fact that good planning and a strong professional organization are essential in successful operations. If these essential factors are present, then the event runs by itself.

In practical terms, being exposed to such pressures in a short period of time would provide students with useful stress management skills, as they became used to reacting under pressure, they stopped feeling the pressure. Students recognized having learnt to remain calm in turmoil, and they expressed the fact that they had developed a capacity to instinctively perceive weaknesses within the team and overcome them by immediately reacting and juxtaposing abilities in a productive way. This means that if there was an individual that found it difficult to face a particular situation due to a personal handicap in a particular area, then others would compensate. In the same way, this individual would assist others in similar situations at another time with his/her strengths.

The key success factors in such an exercise determined the skills that students developed through this "learning by doing" process. These included the ability to stay calm in stressful situations, the importance of being well prepared, and the importance of relying on people in an instinctively clever way, being aware of their drawbacks and strengths and balancing these within the group.

The main motivating factor in such a pressure filled experience was the team spirit and the will to succeed. One clear joint objective and the absolute certainty that the whole group was determined to achieve it together, was not only a powerful driver, but also and above all an invaluable source of everlasting friendship, as trust was the key factor uniting the team.

Such team spirit was certainly developed through the teambuilding exercises organized by the school, but more important than that was the clarity in the objectives. Once established and agreed upon, the next step was "how to fit" the different integrated parts with their preferences and weaknesses. As the tutors in charge were clear in their goals and trusted their students, a climate of mutual confidence was generated. Whenever a problem appeared, students would receive support and the structure was clearly established and communicated, as were the links with Presence Suisse.

When asked about differences in learning through such an intense experience versus learning in the classroom, responses given by the students suggest that the different methods are complementary and each serves to develop a different set of skills. Amongst major learning points from the real events experience, students signaled the capacity to avoid stumbling across difficulties and prioritizing the achievement of a goal through clear focusing. "Survival mechanisms" arise appropriately through intense work while experience challenges you and there is a need to adapt quickly.

Classroom activities, on the other hand, provide a broader view. They allow learners to take the time to look at different facets of the same problem and coordinate views around it. Whereas in the real world, time constraints often prevent thorough analysis as a quick reaction is required, classroom activities allow time to examine problems from different angles and elaborate on perspectives as the pressure is not that eminent.

\section{THE PEDAGOGIC EXPERIENCE: Theoretical Underpinnings Of The Learning By Doing Approach Combined With Classroom Activities}

From a pedagogic point of view, the participation of Cesar Ritz at international sporting events could be described as a major learning experience at the organizational level and also at a personal scale, for the benefit of the particular individuals involved. 


\section{The Organizational Learning Experience}

From the organizational point of view, participating in the House of Switzerland events was an effective way to strengthen links between the Colleges and various local and national stakeholders (i.e. industry partners and government), as well as to develop mutually beneficial relations while cooperating to achieve the satisfaction of their needs, the solution of some of their problems and the understanding of the general environmental landscape. These exchanges have ensured a generalized understanding of the "real world" that reinforced the operational values of the school as aligned to the principles ruling actual good practice in hospitality.

From the individual experience point of view, contributing to these events was presented as a precious opportunity to put into practice in real life the knowledge acquired in the classroom and to return to the school with newly acquired knowledge from a concrete down-to-earth perspective, enhanced by the realism of the actual practice. These learning takeaways are used to update curricular contents provided by the institution in order to ensure their reliability and validity in terms of industry interest.

In terms of Peter Senge (1990:3) learning organizations are “......organizations where people continually expand their capacity to create the results they truly desire, where new and expansive patterns of thinking are nurtured, where collective aspiration is set free, and where people are continually learning to see the whole together.". Participation at the international sports events was certainly a golden opportunity for Cesar Ritz Colleges to learn as an organization as the structures in which its staff and students functioned were conducive to reflection and engagement, which are the main elements of the success recipe as signaled by the author.

Table 1

Cesar Ritz Colleges as a Learning Organization in the light of the International Sport Events experiences

\begin{tabular}{|c|c|c|c|}
\hline $\begin{array}{c}\text { Discipline } \\
\text { (Peter Senge) }\end{array}$ & Action & Consequences & Learning outcomes \\
\hline $\begin{array}{l}\text { Systems } \\
\text { Thinking }\end{array}$ & $\begin{array}{l}\text { Team building exercises, clear } \\
\text { vision and common objectives, } \\
\text { integration within the company } \\
\text { and with partners. }\end{array}$ & $\begin{array}{l}\text { Committed team, solutions- } \\
\text { oriented group, no "blame } \\
\text { culture", no disruptive internal } \\
\text { politics or unnecessary } \\
\text { bureaucracy. }\end{array}$ & $\begin{array}{l}\text { Organization and clear vision are } \\
\text { key to ensure motivation and } \\
\text { objectives completion. } \\
\text { Proper planning allows to solve } \\
\text { unexpected problems effectively. }\end{array}$ \\
\hline $\begin{array}{l}\text { Personal } \\
\text { Mastery }\end{array}$ & $\begin{array}{l}\text { Pressure to react in an efficient } \\
\text { manner, orientation to intuitively } \\
\text { detect strengths and weaknesses } \\
\text { in colleagues and harmonize } \\
\text { teamwork taking these facts into } \\
\text { consideration. }\end{array}$ & $\begin{array}{l}\text { Harmonic teams able to accept } \\
\text { differences and maximize the } \\
\text { outcomes of diversity. }\end{array}$ & $\begin{array}{l}\text { Developed intuition to forecast } \\
\text { weaknesses in other team } \\
\text { members and timely react to } \\
\text { them. }\end{array}$ \\
\hline Mental Models & $\begin{array}{l}\text { Constraint to operate in diverse } \\
\text { teams (in terms of nationalities, } \\
\text { abilities, learning preferences, } \\
\text { etc.) }\end{array}$ & $\begin{array}{l}\text { Synergetic operations in which } \\
\text { each person was contributing } \\
\text { with his/her strengths to } \\
\text { compensate for other member's } \\
\text { weaknesses }\end{array}$ & $\begin{array}{l}\text { Diversity is a source of } \\
\text { innovation and a motivator to } \\
\text { think outside the box. Creativity } \\
\text { is enhanced by juxtaposition of } \\
\text { contrasting views for as long as } \\
\text { this takes place in a respectful } \\
\text { and harmonic context. }\end{array}$ \\
\hline $\begin{array}{l}\text { Building } \\
\text { Shared Vision }\end{array}$ & $\begin{array}{l}\text { Clear establishment and } \\
\text { communication of the objectives } \\
\text { and clear structures }\end{array}$ & $\begin{array}{l}\text { No confusion or disappointment, } \\
\text { no false expectations, motivation } \\
\text { to see goals achieved. }\end{array}$ & $\begin{array}{l}\text { Trust is a source of productivity. } \\
\text { Loyalty is a value. }\end{array}$ \\
\hline $\begin{array}{l}\text { Team } \\
\text { Learning }\end{array}$ & $\begin{array}{l}\text { Inception of the experience in the } \\
\text { curriculum. Links with industry } \\
\text { that promoted mutual beneficial } \\
\text { exchanges that went beyond } \\
\text { economic interests }\end{array}$ & $\begin{array}{l}\text { Strengthen teams, generalized } \\
\text { motivation, personal commitment } \\
\text { in tasks, loyalty. }\end{array}$ & $\begin{array}{l}\text { Richer curricula, continuously in- } \\
\text { line with latest industry } \\
\text { developments. Strengthened, } \\
\text { productive teams. }\end{array}$ \\
\hline
\end{tabular}


Students' statements on the major motivational factors that pushed them to work under such pressure during the events and moreover, to be willing to do that again on the next occasion coincide perfectly with Senge's description of how organizations learn and how they ensure the perpetuation of their own success. "When you ask people about what it is like being part of a great team, what is most striking is the meaningfulness of the experience. People talk about being part of something larger than themselves, of being connected, of being generative. It become quite clear that, for many, their experiences as part of truly great teams stand out as singular periods of life lived to the fullest. Some spend the rest of their lives looking for ways to recapture that spirit." Senge (1990: 13)

The learning experience organization wise was intuitively based on the five pillars that Senge (1990) presents in his thesis: Systems thinking (integrating others in a cohesive body of theory and practice), Personal mastery ("continually clarifying and deepening our personal vision, of focusing our energies, of developing patience, and of seeing reality objectively", (Senge 1990:7)), Mental models (fostering openness through the contrasting of personal mental frameworks with contradictory paradigms), Building shared vision (establishing a picture of the future that is to be created) and Team learning ('the process of aligning and developing the capacities of a team to create the results its members truly desire' (Senge 1990: 236). Table 1 illustrates areas in which participation at the international sports events contributed to the growth and learning of Cesar Ritz Colleges as an organization.

\section{The Individual Learning Experience}

From the individual/student perspective, the whole process of learning through the participation in the House of Switzerland could be straightforwardly described by using Kolb's (1984) model. Applying this theoretical framework to the exercise in question provides a concrete example of how cognitive processes of knowledge inception can be continuously reinforced by their systematic matching with reality. Figure 2 illustrates how participation in the House of Switzerland activities leads to reflective observation in students (through classroom analysis and developments around the concrete experience); and then how theory follows next (under the format of theory development in the production of academic papers, under-graduate and post-graduate dissertations, etc. and their dissemination), to finally close the cycle with active experimentation (contribution to the industry in terms of actually working) that will enrich in different ways the initial or subsequent experiences with a realistic and useful perspective.

Matching up the previously explained model with Honey \& Mumford's (1982) on preferred learning styles, the Cesar Ritz participation in international sports events experience shows its potential as a comprehensive method that allows at the same time to draw on the natural capacities and individual preferences of each diploma candidate, as well as to develop these areas that are not the most likely to be spontaneously chosen by each one of them in a harmonious manner. This way, for example a student who is an "activist" (prefers doing and experiencing), will find it effective and easier to learn by contributing to a concrete and realistic new project. A student who is a "reflector" (likes to observe and reflect), will take maximum profit from linking up the experience to other similar ones described or simulated in a formal/traditional classroom. A student with "theorist" preferences (wants to understand underlying reasons, concepts and relationships), will find in this exercise material for articles and dissertation production and knowledge codification, whereas a "pragmatist" (likes to try things to see if they work) will enjoy links with the industry as a means to test previously acquired theoretical knowledge.

The participation at the international sports events as a learning exercise therefore does favor the development of in-born or already-acquired capacities along with providing a more generalist approach that favors the use of a preferred style for learning, thus preventing biases in favor of these students using a particular method. On the other hand, as all skills and learning techniques are to be used at one moment or another during the learning process, students are obliged to develop other ways of acquiring knowledge than the preferred one.

Equally important, the developed teambuilding culture strongly contributes to the harmonization of different in-born learning perspectives, as students quickly learn under pressure that it is necessary in order to achieve objectives to compensate one member's weaknesses with other member's strengths. In this way, for example, a student who is a "reflector" and therefore would perform better in theoretical modules would be assisting 
in that area one that is an "activist" and that would be more inclined to perform better in other type of activities, such as the practice of the profession in a highly stressful intensive short-period situation.

Hudson (1967) signaled that traditional educational methods privilege convergent ways of learning, as these are based on the grouping of several facts or principles around a particular topic. As when that being the case, it is possible to define a single or a group of possible answers as "right", as opposed to others that are defined as "wrong", in many cases students who have developed this preferred thinking style tend to have higher scores than others. In the opposite quadrant to this preferred option, there are those who think in a divergent way, which is generated as a combination of concrete experiences and subsequent reflective observation. Divergent thinkers are more innovative in the sense that their input is based to a great extent on intuition and insights (like in art) and therefore the subjectivity of their approach does not facilitate its appreciation when grading. In traditional learning establishments, divergent thinkers tend to be unwillingly penalized because they do not always fit within the marking criteria and their personal input is not valued. A clever combination of different learning methods, allowing everyone to express their capacities and strengths in different moments is not only a fair solution, but also an integrative way to maximize social, economic and generalist positive outputs.

Figure 2 illustrates in which ways the House of Switzerland and the European Youth Olympic Festival exercises, combined with traditional learning methods offer a comprehensive integration of different approaches at different stages of the exercise including a strong and continuous interface with the industry that is reflected in the formalization of the knowledge transfer through the curriculum development and its codification for dissemination. This implies the development of activities of different natures that allow students with different capacities to profit dramatically from the whole experience whatever their orientation could be, in a much more equalitarian and nondiscriminatory manner than the usual ways of teaching can offer. From a Piaget (see Satterly in Gregory, 1987) perspective, this method of learning assists in the cognitive harmonization of the assimilation of new inputs (through confrontation with reality and the stimulation of natural mechanisms for dealing with the unknown) with the consequent accommodation process of placing the newly acquired knowledge within the framework of what is already known (through the inception of the lived experience in the curriculum and in the normal school activities).

Both convergent and accommodative processes can be described as public processes (Atherton, 2005) in the sense that they are about making sense out of what is perceived as an outside reality (the "real world" or the "industry world"). Divergent and assimilative processes are considered to be private processes (Atherton, 2005), as they have to do with subjective internal cognitive mechanisms of understanding. Figure 2 shows the relationship between the mentioned concepts as well.

In terms of Kolb (1984), knowledge can be acquired either by direct experience , in which case it is "apprehended", as per when direct links with the industry take place or in practical experiences such as active participation in the international sports events; or else it can be "comprehended", which means that it is acquired through abstract conceptualization, like when theory is produced. According to Atherton (2005), the apprehension process appears as public, whereas the comprehension would be private. Also in terms of Kolb (1984), once the knowledge has been acquired by either of the previous paths or a combination of both, the basic ways of transforming it are either by "denotation" (by using it, like in the case of the banqueting exercises, the organization of the press conferences, etc.) or by "connotation" (by thinking of it, like in the case of reflection in class after the exercise) or when producing reports/dissertations and other pieces of work based on it. Once again, participation at Olympic events and their inception in the general organization and running of the school presented a comprehensive example of compatibility of different learning approaches to the same phenomenon from different angles.

Figure 2 illustrates how the inception of the House of Switzerland experience as a learning exercise enhances each one of Kolb's stages in the learning process, how preferred learning styles are incorporated in it, and it also shows in which ways this theoretical/practical approach provides a comprehensive learning experience that allows all types of students, with their particular learning styles to acquire knowledge in a holistic-comprehensive manner. 
Figure 2

The Coventry University Model for Active Learning

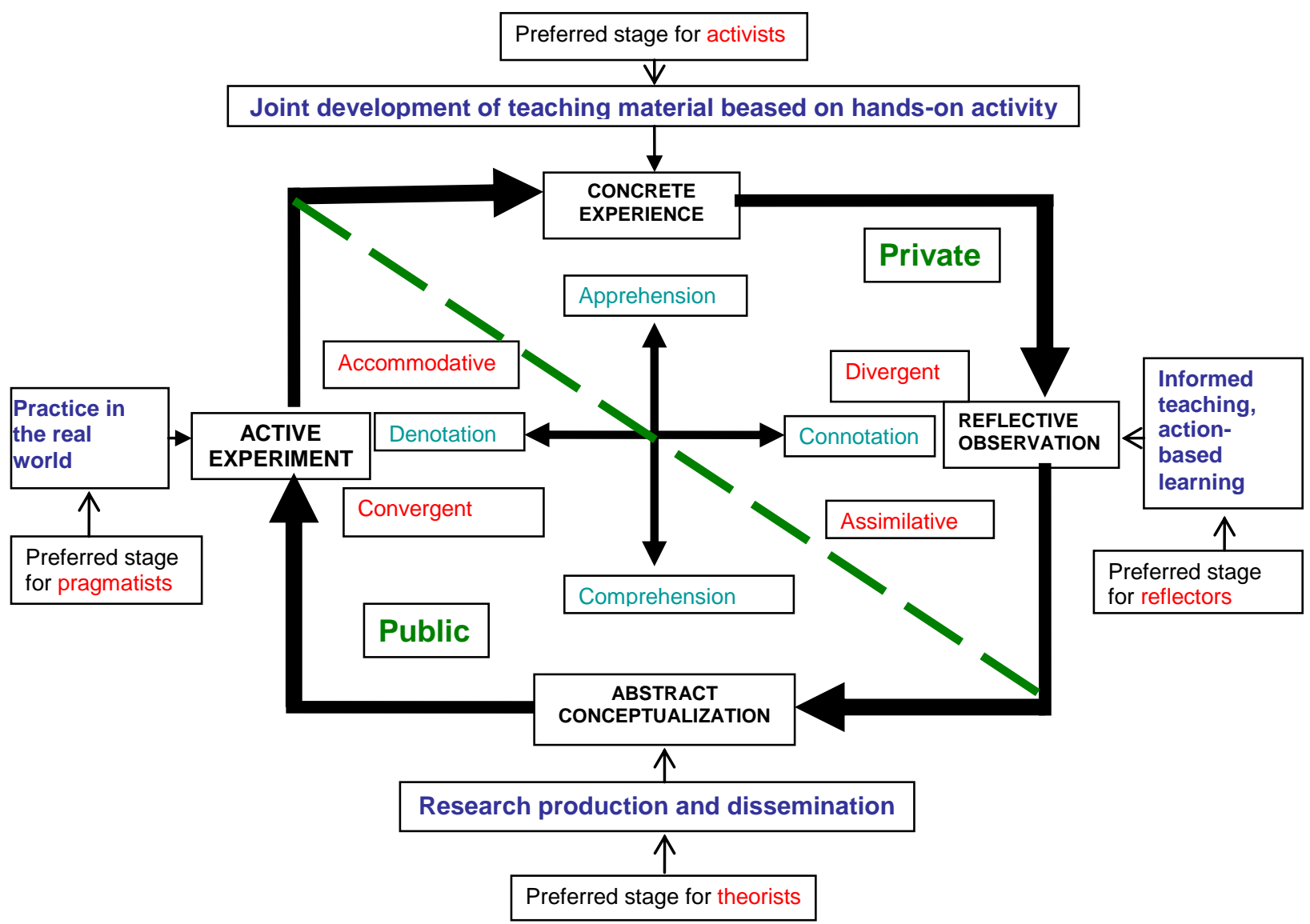

\section{CONCLUSIONS}

Theory shows that a balanced combination of different learning methods including traditional reflective activities, theory production and industry confrontation not only lead to higher student satisfaction and to a more productive holistic pedagogic experience, but also allow different personalities to maximize knowledge inception through the opportunity of approaching reality in their preferred way.

The Cesar Ritz Colleges method, that combines classroom experience with real life events incorporating real life activities in their curriculum in a cohesive manner allows students to develop both using their in-born individual capacities in a non-discriminatory manner (as it is not only one way of learning that is privileged over others, giving everyone the same right to excel through the maximization of their own individual talents). At the same time, this multi-resource learning approach inspires students to develop capacities that they would not otherwise naturally exploit (reflection if someone is more action-oriented or vice versa, for example), whereas creating a team-work environment in which individual challenges are faced as a group, allowing colleagues to mutually support each other in activities where they do not necessary have a competitive advantage.

Participation at international sports events has proven to be for Cesar Ritz Colleges a means to strengthen links with the industry, and to integrate practical aspects of the profession in the curriculum taking into consideration the most updated production and operational techniques and the views from recognized practitioners in the field. 
Cesar Ritz Colleges as an institution benefited from this experience, which reinforced a positive corporate culture and motivated its staff and students in the pursuit of common goals.

Both theory and practice have shown that the combination of various learning approaches resulted in a favorable learning experience that was

- Non-discriminatory: as it does not unfairly favor students with a specific learning preference in detriment of others,

- $\quad$ Team-building oriented: activities are very much reliant on mutual trust and complementation,

- Strongly linked to the industry: because industry and government institutions act as partners,

- $\quad$ Continuously self-improved: because the organization is learning itself through the practice,

- International in nature: as it takes place internationally with international students,

- $\quad$ Respectful of diversity: at different levels as described below.

\section{THE WAY FORWARD}

Cesar Ritz Colleges will almost certainly be showcasing their capacity to innovate through the constructive development of new ideas and practices resulting from the open discussion and synergistic approach to diversity at different levels including: national diversity, diversity in learning preferences, diversity in personalities and in opinions. Their next chance to implement once again this successful methodology is going to be in China at the Beijing 2008 Olympic Games.

The Olympic games in London in 2012 could be a fascinating opportunity for British educational Institutions to emulate such processes and build on relationships with industry, government, local producers and other stakeholders in the development of successful pedagogic innovative methodologies like the one described in this article. The experience of these Sports Events has been included as a life event, as well as the themed banquets, alumni reunions and open house are included in the HM2 Higher Diploma curriculum and featured within the CNV2730 Events Management subject each term. Annex one provides with the Module Descriptor for this module.

\section{REFERENCES}

1. Atherton J S (2005) Learning and Teaching: Experiential Learning [On-line] UK: Available: http://www.learningandteaching.info/learning/experience.htm Accessed: 12 April 2007.

2. Honey P and Mumford A (1982) Manual of Learning Styles London: P Honey

3. Hudson L (1967) Contrary Imaginations; a psychological study of the English Schoolboy Harmondsworth: Penguin

4. $\quad$ Hueter M (2006). Schlussbericht von Prasenz Schweiz. House of Switzerland Torino 2006.

5. Kolb D A (1984) Experiential Learning: experience as the source of learning and development New Jersey: Prentice-Hall (0 13295261 0)

6. Mistelbauer K (2006) Tourism Promotion at Sports Events: The House of Austria of the XX Olympic Winter Games Torino 2006. Unpublished Master Thesis.

7. Satterly D (1987) "Piaget in Education" in R L Gregory (ed.). The Oxford Companion to the Mind. Oxford, Oxford University Press.

8. $\quad$ Senge, P.et al. (1990) The Fifth Discipline Fieldbook: Strategies and Tools for Building a Learning

Organization. New York: Doubleday/Currency. 
Annex 1: Module Indicator Descriptor for CNV2730 Events Management

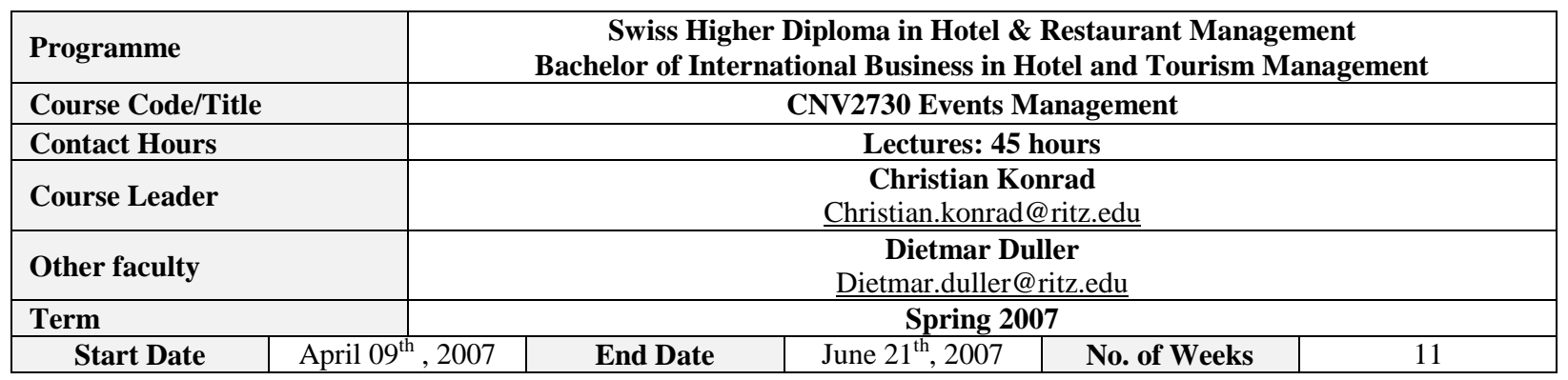

\section{RATIONALE}

Many hotels are striving for ways to increase their room occupancy and yield. A recognised area of growth for many hotel properties is meetings, incentives, conventions and events, also known as the MICE industry. Given the competition for MICE consumers, it is imperative that staff are trained in all areas of event management in order to procure the business. Practical event management skills will prepare the student for work in this sector.

\section{AIM}

The aim of this course is to introduce students to the main principles of event management. It will offer a practical and comprehensive overview of the current global environment in which events are conducted, reflecting how the field has developed in recent years and where it is going. The major theoretical and practical emphasis is on staging of an event.

\section{LEARNING OUTCOMES}

Upon completion of this course, the student will be able to demonstrate the following learning outcomes:

1. Define an event and what is meant by event management

2. Define stakeholders of events, why it is important and how to satisfy stakeholders

3. Identify the steps in event management including critical path theory

4. Demonstrate effective group management and functionability

5. Successfully plan, organise, lead and control an event

\section{TEACHING AND LEARNING STRATEGY}

Lectures, group work, interactive workshops, guest speaker(s), simulation, videos, and practical exercises.

\section{ESSENTIAL READING}

There is no essential reading for this course. Students are encouraged to access the recommended reading as well as cookery books, trade magazines and journal articles.

\section{RECOMMENDED READING}

1. Abbey, J.R. (1998) Hospitality sales and marketing. ( $3^{\text {rd }}$ ed.). Lansing: Educational Institute of the American Hotel \& Motel Association.

2. $\quad$ Astroff, M.T. \& Abbey, J.R. (1998). Convention sales and services. ( $5^{\text {th }}$ ed.). Cranbury, NJ: Waterbury Press.

3. Bowdin, G.A.J., McDonnell, I., Allen, J.\& O’Toole, W. (2001). Events management. Oxford: ButterworthHeinemann.

4. Goldblatt, J. (2002) Special Events: Twenty-First century Global Event Management. New York, NY: John Wiley \& Sons Ltd.

5. Weitz, B.A., Castleberry, S.B. \& Tanner, J.F. (1997). Selling: building partnerships. (3 ${ }^{\text {rd }}$ ed). McGraw-Hill. 


\section{WEEK-BY-WEEK SCHEME}

\begin{tabular}{|c|c|c|}
\hline Week No. & $\begin{array}{c}\text { Date } \\
\text { Week Beginning }\end{array}$ & Topics \& Readings \\
\hline 1 & 09 April & $\begin{array}{cl}\text { Topic: } & \\
\bullet \quad \text { Introduction } \\
\bullet \quad \text { The event industries - Case Study: House of Switzerland } \\
\text { Activity: Stakeholder identification and group functionality }\end{array}$ \\
\hline 2 & 16 April & $\begin{array}{ll}\text { Topic: } & \\
\text { - Progress and discussion of class event 25.05.2007 } \\
\text { - } \\
\text { Activity: } \\
\text { - Ments - Social and economic role } \\
\text { - Group activities and meetings } \\
\text { - Case study } \\
\end{array}$ \\
\hline 3 & 23 April & $\begin{array}{cl}\text { Topic: } & \\
- & \text { Progress and discussion of class event 25.05.2007 } \\
\text { - } & \text { Events - Types of events } \\
\text { Activity: } & \\
- & \text { Meet with client / discussion } \\
\text { - } & \text { Group activities, exercises and meetings } \\
\end{array}$ \\
\hline 4 & 30 April & $\begin{array}{ll}\text { Topic: } & \\
\text { - Progress and discussion of class event } 25.05 .2007 \\
\text { Activity: } \\
\text { - } \text { Ments - Role and skills of the Event Manager } \\
\text { - } \text { Group activitient / discussion } \\
\text { - Case study }\end{array}$ \\
\hline 5 & 07 May & $\begin{array}{ll}\text { Topic: } & \\
- & \text { Progress and discussion of class event 25.05.2007 } \\
\text { - } & \text { Events - Impacts of events } \\
\text { Activity: } & \\
\text { - } & \text { Meet with client / discussion } \\
\text { - } & \text { Case study activities, exercises and meetings } \\
\end{array}$ \\
\hline 6 & 14 May & $\begin{array}{cl}\text { Topic: } & \\
\text { - } & \text { Progress and discussion of class event } 25.05 .2007 \\
\text { Activity: } & \text { Events - Developing and event and balancing conflicting needs } \\
\text { - } & \text { Meet with client / discussion } \\
\text { - } & \text { Group activities, exercises and meetings } \\
\end{array}$ \\
\hline 7 & 21 May & Event \\
\hline 8 & 28 May & Event Review / Analysis \\
\hline 9 & 04 June & $\begin{aligned} & \text { Topic: } \\
&- \text { Events - Mission and vision } \\
& \text { - Objectives and organizational structures } \\
& \text { Activity: } \text { FAQ } \\
&\end{aligned}$ \\
\hline 10 & 11 June & Examination Week \\
\hline
\end{tabular}




\section{ASSESSMENT}

\begin{tabular}{|c|c|c|c|}
\hline No. & Due Date & Coefficient & Assessment Type \\
\hline 1 & Ongoing & 2 & Class participation \\
\hline 2 & Week 8 & 4 & Staging and event \\
\hline 3 & Week 9 & 2 & Event folder \\
\hline 4 & Week 10 & 2 & Final examination \\
\hline
\end{tabular}

\section{ASSESSMENT 1}

\section{Instructions:}

Assessment one consists of class participation and related home work.

\section{Assessment Objectives or Rationale:}

The objectives of this assessment are to ensure that students understand the materials covered over this time period and that they actively engage in their learning. This understanding is indicated by satisfactory completion of home work, group work and class participation as specifically addresses learning outcomes 4 and 5.

\section{Assessment Task:}

Satisfactory class participation is indicated by a student's ability to contribute to class discussions. All students are expected to attend scheduled group meetings, help set group goals and objectives and achievement of these objectives.

\section{Assessment Criteria:}

Students will be graded according to their contribution to class. Students who do not participate cannot expect a pass grade. Similarly, those students who are disruptive in either the class or in group work outside of class cannot expect to pass.

\section{Feedback and Evaluation:}

The final grade for assessment one shall be available during the last week of term.

\section{ASSESSMENT 2}

\section{Instructions:}

Students are expected to stage an event for a designated client, meeting the needs of the client and any other stakeholders.

\section{Assessment Objectives or Rationale:}

To assess objectives $1,2,3,4 \& 5$

\section{Assessment Task:}

As events can vary due to clients' wishes, the details of this task are generally a combination of the information provided by the client and the imagination and creativity of the team. 


\section{Assessment Criteria:}

In assessing the event, the following criteria will be taken into account:

- $\quad$ The event theme - applicability and consistency in approach

- $\quad$ Planning - how well the event was planned, types of plans and group functionality

- $\quad$ Organising - how well the team was organised, the type of organisation and training

- $\quad$ Leading - ability to manage the event, motivate, ability to set and follow instructions

- $\quad$ Controlling - quality assurance

- $\quad$ Ability to meet the needs of stakeholders - the overall impact of the event

- $\quad$ Team work - this includes liaison with other departments/stakeholders

Individuals are also reviewed using the peer review form to be provided. Each student should review the contribution of each group member to the overall project outcome, with adjustments made to individual grades to reflect contribution.

Feedback and Evaluation:

Feedback will be provided within 1 to 2 weeks of submission.

\section{ASSESSMENT 3}

\section{Instructions:}

A comprehensive event folio must be prepared on the event (see assessment 2).

\section{Assessment Objectives or Rationale:}

To assess objectives $1,2,3,4 \& 5$

\section{Assessment Task:}

A folio or folder must be prepared as a summary of the event and its management. Further details of the folio content shall be provided.

\section{Assessment Criteria:}

In assessing the report and presentation, the following criteria will be taken into account:

- Interpretation of the task

- $\quad$ Development of a logical and well ordered folio

- $\quad$ Ability to organise relevant material to support your choice of event theme, and the staged event

- $\quad$ Knowledge of relevant event management tools

- $\quad$ Clear and well supported conclusions

- $\quad$ Constructive feedback about group progress

- Clarity, style and coherence of the written and oral expression

- $\quad$ Referencing and presentation.

\section{Feedback and Evaluation:}

Feedback will be provided within 1 to 2 weeks of submission. 


\section{ASSESSMENT 4}

\section{Instructions:}

A test will be held during the examination week (11). The test can consist of multiple choice, short answer open-ended questions, an essay and/or case studies. The test consists of all materials in whatever form covered from week 1 to 10 .

\section{Assessment Objectives or Rationale:}

To assess objectives $1-5$

\section{Assessment Task:}

The test will be held for 2 hours. Students should study the questions carefully and allocate the amount of time they need to spend on each question according to the number of marks awarded for each question. Additionally, students must write their answers clearly and accurately to avoid any misunderstanding between the students and lecturers. No paper or electronic dictionaries are allowed during these tests.

\section{Assessment Criteria:}

Open-ended exam questions will be graded according to the materials being presented and taught during contact time. Students' opinion and experience will be taken into consideration in attempting the questions. However, their opinion and experience must be logical and precise. With reference to case studies, answers will be graded according to logical arguments and precision in answering the questions. Marks will not be awarded when the lecturer is unable to comprehend the English expression. The lecturer will clarify all assessment criteria during contact time.

\section{Recommended Reading:}

Good grades will depend on evidence of wider reading.

\section{NOTES}




\section{NOTES}

